\title{
Exploring of Salt tolerant Biocontrol Agent (STBA) against Phytopathogen of Mustard Crop (Brassicae junecea)
}

\author{
Kusum Sharma $^{1 *}$, Swati Sharma ${ }^{1}$, Pawan Sharma ${ }^{2 *}$ and S. Rajendra Prasad ${ }^{3}$ \\ ${ }^{1}$ Integral University, Lucknow, U.P, India \\ ${ }^{2}$ ICAR-National Bereau of Agriculturally important microorganism, Mau, U.P, India \\ ${ }^{3}$ University of Agriculture and Sciences, Bangalore, India \\ *Corresponding author
}

\section{A B S T R A C T}

\section{Keywords}

Biocontrol agent, Abiotic stress, biotic stress

Article Info

Accepted:

20 August 2019

Available Online:

10 September 2019
Plant diseases have a major adverse effect on the crop yield and these can controlled by the biological approach by using PGPRs. Mustard crop suffers due to the increased number of abiotic and biotic stressors which affects its growth and yield. Now a day's PGPR are being widely used worldwide, due to their eco-friendly nature and is considered as traditional agricultural technique. Keeping in view theabove problem, the present study has been conducted to explore the biocontrol agents along with their Plant Growth Promoting activities. A total of 300 bacterial strains were isolated from the rhizospheric soil of mustard crop. Further, twenty five bacterial strains were identified as salt tolerant rhizobacterial strains in $10 \%$ of $\mathrm{NaCl}$ supplemented Nutrient Agar Media. Only eight bacterial strains B1, B3, B9, B10, B11, B1, B14, B17 and B22 were found promising for their antagonistic activity against Alternaria brassicae plant pathogen. The percentage of inhibition varied from $31 \%$ to $42 \%$ under in-vitro condition. These bacterial strains were tested for other traits like HCN, Siderophore and Amylase production. Results showed that all the eight bacterial strains produced $\mathrm{HCN}$, ranging from $20 \%$ to $60 \%$. Out of eight bacterial strains, six bacterial strains showed potentiality for siderophore production ranging from $28 \%$ to $63 \%$ and five produced amylase ranging from $20 \%$ to $60 \%$.

\section{Introduction}

Rapeseed-mustard is the one of the most important post-rainy (winter, October-March) oilseed crop in India. Mustard is a glycophyte crop cultivated in the arid and semi-arid areas of the world and is adversely affected by saline stress (Srivastava et al., 2015). It has been reported that growth and yield of the crop is considerably affected due to several abiotic and biotic stress factors, (Prasad et al., 2011; Atkinson et al., 2013; Narsai et al., 2013; Prasch and Sonnewald, 2013; Suzuki et al., 2014; Mahalingam, 2015; Pandey et al., 2015a; Ramegowda and Senthil Kumar, 2015). It was found that influence of 
occurrence and pathogen spread was due to the salinity an abiotic stress factor (TrikyDotan et al., 2005; Roubtsova and Bostock, 2009). Phytopathogen Alternaria brassicae is one of the causative agent of alternaia blight diseases which is a serious threat to mustard (Brassica juncea) cultivation (P. Chomoczynski, and N. Sacchi, 1987). This diseases can infects the plants at all the stages of their growth and negatively affect both quality and quantity oil yielding of the crops (Meena et al., 2010). It is reported that in India Alternaria blight is a most common destructive diseases of mustard crop (S. J. Kolte, 1985) causes yield loss of varies from 10.0 to 70.0 per cent (Kumar and Kolte, 2001). Infectious seed causes oil yield loss ranges between 15\%-36\% has been reported by A.N. Ansari (1988). Worldwide to control the plant diseases occur due to the ingestion of synthetic pesticides, a huge amount of money is being spent. PGPR with combinations of different mechanisms of action in plants allowing the improved crop yields and is also helpful for good health of crops. PGPRs associated with plant roots offer enhanced plant growth and stress alleviation by various means.

Plant growth promoting rhizobacteria found on the plant root surface can enhance plant growth and abiotic and biotic stress alleviation by the various mean. A practice use rhizobacteria in agricultural field can overcome the harmful effect of synthetic fungicide on environmental and health concerns (Raupach and Kloepper 1998; Kobayashi et al., 2002). PGPR-mediated Biocontrol strains even under saline condition against an array of phytopathogens can reduce several plant diseases have been reported (Paul and Nair 2008; Triky-Dotan et al., 2005). Inhibition of infectious pathogens by using another potential microorganism is Biocontrol mechanism (Cook, 1993; Baker, 1991). Potential biological control agents were remaining same even under stress conditions indicate Biocontrol can sustain even under advers conditions also (Diby et al., (2005a).

Keeping in view the economic value of the crop for the region and extensive damaged caused by Alternaria blight diseases, the present study was conducted to find out the suitable eco- friendly strategy which can act as Biocontrol agents (PGPR) against the Alternaria blight diseases.

\section{Materials and Methods}

\section{Soil sampling}

Mustard rhizophere soil samples for the isolation of halotolerant Biocontrol agents were collected from the salt affected area of four districts of U.P. viz Mau, Ballia, Gorakhpur and Varanasi during winter season (Nov-Dec) of 2016. Four villages from the each district were selected for the soil sampling and total of 16 soil samples were collected from the different locations. Uprooted mustard plants were kept in the sterile polythene bags, labelled and tied it. Subsequently soils were dried under shade condition and make pooled them locations wise.

\section{Isolation of bacteria}

Isolation of bacteria from the rhizospheric soil was done by serial dilution method. From the rhizosheric soil $0.1 \mathrm{~g}$ of soil is suspended in 1 $\mathrm{ml}$ of distilled water and makes further dilutions from $10^{-1}$ to $10^{-5}$ after that $0.1 \mathrm{ml}$ of diluted soil suspension $\left(10^{-4}\right.$ and $\left.10^{-5}\right)$ is spread over the surface of the Nutrient agar plate. The inoculated plates are incubated at $37^{\circ} \mathrm{C}$ for $24-48$ hours. During the incubation period bacterial cell on the agar plate grows and multiplies rapidly to produce a mass of bacteria cells called a 'colony'. All the visible single colony of bacterium was separate out 
by streaking method and each pure bacterial isolate in $40 \%$ of glycerol stock was keep in 20 refrigerator for the long term storage.

\section{Screening of Salt Tolerant Bacterial Isolates}

Screening of Salt Tolerant Bacterial isolates was done in the medium containing $\mathrm{NaCl}$. A salt amended modified media was prepared by adding $10 \%$ of $\mathrm{NaCl}$ in Nutrient Broth (NB) and Nutrient Agar (NA) medium. A 48 hrs old fresh bacterial culture of $50 \mu \mathrm{l}$ was inoculated in the NB medium and for the plate assay a pure colony of bacteria was streaked on modified NA medium.

Both bacterial streaked plates and Nutrient Broth was incubated at $37^{\circ} \mathrm{C}$ with for $48-72$ hrs. After completion of incubation period bacterial growth in NB was recorded by taking $\mathrm{OD}$ at $600 \mathrm{~nm}$ and in NA plate Salt tolerant bacteria (STB) was screened by the visible different colony of bacteria.

\section{Dual culture assay}

The antagonistic activity of Potential PGPR against Alternaria species was tested by dual culture technique. Two bacterial strains were streaked on the both sides of PDA plates with the test fungal pathogen which was kept in the centre of the plate and a fungal disc alone in a separate Petri-dish served as control and kept it for the incubation at $24 \pm 2{ }^{\circ} \mathrm{C}$ for 5-7 days. Percentage of inhibition zone was recorded on the basis of the mycelia growth of fungal pathogen by using the formula Per cent inhibition $(\mathrm{I})=\mathrm{C}-\mathrm{T} / \mathrm{C} \times 100$ (Riungu et al., 2008) :

Where, C- mycelial growth of pathogen in absence of antagonists

T- mycelial growth of pathogen in presence of antagonists.

\section{Extracellular Enzyme production}

All the bacterial isolates were tested for starch hydrolysis as described by Bernfeld. et al., 1955. Bacterial streaked starch enriched agar $(1 \% \mathrm{pH} 7.2)$ plates were incubated at $37^{\circ} \mathrm{C}$ for 24 to 48 hrs. After then Lugol's iodine solution in ratio of (1: 5 Lugol's iodine: dist. $\mathrm{H}_{2} \mathrm{O}$ ) was flooded over the plates. Appearance of a transparent zone around the bacterial colony indicated production of amylase. This halo was measured for subsequent calculation of the enzymatic index by dividing halo size by colony size (Alves et al., 2002).

\section{Hydrogen Cyanide Production}

HCN production test of potential bacterial isolates was examined as per the method described by Bakker and Schipper 1987. King's B Agar medium amended with glycine $(4.4 \mathrm{~g} / \mathrm{L})$ was prepared and overnight kept it for the solidification. Each bacterial isolates were streaked on a single separate plate and lid of each Petri plate was covered with Whatman no.1 filter paper soaked in $0.5 \%$ picric acid in $2 \%$ sodium carbonate and incubated at $30-35^{\circ} \mathrm{C}$ for 5-7 days. Results was observed due to the Change of colour from yellow to orange and then to dark brown in the filter paper indicated as positive reaction and the absence of change colour as negative reaction.

\section{Siderophore Production}

Siderophore Production test was performed by following the method given by Schwyn and Neilands (1997). Universal CAS assay medium on agar plate was prepared and each bacterial strain was inoculated in the middle of the plate and incubate at $30^{\circ} \mathrm{C}$ for $2-5$ days. Siderophore producing bacteria was identified by CAS-agar colour changed from blue to orange, purple, or magenta. Un-inoculated control plates of CAS-agar was incubated 
under the same conditions as described above was found with no colour change in the CASblue agar. Change of colour from orange, purple, or magenta colour indicated as positive reaction for siderophore Production test and the absence as negative reaction.

\section{PCR amplification}

The PCR amplification of 16S rRNA genes of bacterial strains was done with an universal 16s rRNA forward primer PA (5'AGAGTTTGATCCTGGCTCAG-3') $1 \mu 1$ reverse primer $\mathrm{PH}$ (5'-AAGGAGGTGAT CCAGCCGCA-3'). $25 \mu$ l of PCR mixture contained $1 \mu \mathrm{l}$ forward primer PA $1 \mu 1$ reverse primer $0.5 \mu \mathrm{l}$ of bacterial lysis and $10 \mu \mathrm{l}$ of nuclease free water in a PCR tube for each bacterial strain. Thermal cycling consisted of the following steps: $94^{\circ} \mathrm{C}$ for $3 \mathrm{~min}$, followed by 35 cycles of $94^{\circ} \mathrm{C}$ for $1 \mathrm{mint}, 52^{\circ} \mathrm{C}$ for $1 \mathrm{mint}, 72^{\circ} \mathrm{C}$ for $1 \mathrm{mint}$, and a final step at $72^{\circ} \mathrm{C}$ for $10 \mathrm{~min}$. PCR products were electrophoreses through a $1.2 \%$ agarose gel in $0.5 \mathrm{X}$ Tris-borate-EDTA buffer and visualized under the UV light in a gel documentation system (BIORAD, India). PCR products of all potential bacterial isolates were outsourced for partial 16s sequencing from omega biotech limited (Kanpur (India) Pvt. and identification of bacterial strains at genus and species level was done by using NCBI BLAST searches.

\section{Results and Discussion}

Out of 300 bacterial isolates from rhizospheric soil samples, twenty five could grow in $10 \%$ of $\mathrm{NaCl}$ medium and out of these 25 isolates, only eight bacterial strains showed antagonistic activity against $A$. Brassicae under in-vitro condition.. All the eight bacterial strains were tested for other Biocontrol activities like HCN production, Siderophore production and Starch solubilisation. These eight bacterial strains were identified as genus Bacillus and
Enterobacter by using $16 \mathrm{~s}$ sequencing. Bacterial strains B3 and B22 were identified as genus Bacillus (Table 1) and rest other bacterial strains B8, B9, B12, B15, B17 and B20 were identified as genus Enterobacter (Table 1). The sequences of the isolates were submitted to Gen Bank under accession numbers MK 418219, MK 4711330, MK 463942, MK 463943, MK 463952, MK 478371, and MK530649 (Table 1).

\section{PGPR traits}

\section{Dual culture method}

All the 25 Salt Tolerant Rhizobacteria (STR) bacterial strains were tested for their antagonistic activity against Alternaria Brassicae. It was found that out of 25 STR strains 8 bacterial strains B1, B3, B9, B10, B11, B14, B17 and B22 identified as genus enterobacter and Bacillus (Table 1) were found to be antagonistic to Alternaria Brassicae (fig and Table 2). Bacterial strains were found to inhibit pathogen and the inbibition ranged from $22.75 \%$ to $44.4 \%$ under in-vitro condition. Maximum zone of inhibition (Table 2 and Fig 1, 2, 3, 4) was shown by bacterial strains B4 and B20 identified as genus Bacillus and Enterobacter (Table 1).

\section{Siderophore production}

The ability of rhizobacteria to produce siderophores has been the focus of many studies dedicated to investigating PGPR (Maksimov et al., 2011). All the 25 bacterial strains were tested for the siderophore production and it was found that $64 \%$ of STRs are able for the production of Sidereophore and only $16 \%$ bacterial strains were found positive for both siderophore production and antagonistic activity. The siderophore production by four bacterial strains viz B3, $\mathrm{B} 8, \mathrm{~B} 15$ and $\mathrm{B} 17$ ranged from $52.38 \%$ to 
$63.15 \%$ (table 1). Bacterial strain B17 identified as genus Enterobacter was found to exhibit the highest $(63.15 \%)$ siderophore production activity (table 1).

\section{HCN Production}

$68 \%$ of bacterial strains were found to be positive for $\mathrm{HCN}$ production test. Only five bacterial strains viz B3, B4, B, B15 and B17 were found to be positive for $\mathrm{HCN}$ production and antagonism. Maximum HCN production was seen in bacterial strain B15 in plate assay method.

\section{Starch solubilisation Test}

Starch solubilisation was determined by the appearance of halo zone and is indicative of areas of hydrolysis by bacterial strains. $36 \%$ bacterial strains were found to have starch solubilisation activity and only five, out of eight bacterial strains viz B3, B4, B9 B12 and B17 showed both the traits of antagonism and starch hydrolysis. The range for starch solubilisation for all the five bacterial strains was calculated between $20 \%$ to $60 \%$, B4 and B12 strains showed highest starch solubilisation activity (60\%) as compared to other bacterial strains.

In order to alleviate the advese effects of biotic and abiotic stresses on plants, we need to have the biocontrol agents having salt tolerant activities. Bacterial isolates B1, B3, B9, B10, B11, B1, B14, B17 and B22 showed similarity with the genus Enterobacter and Bacillus. Biocontrol agents have been reported to be effective against an array of pathogens even under saline stress conditions (Elmer 2003; Paul and Nair 2008; Rangarajan et al., 2003; Triky-Dotan et al., 2005). Bacterial colonisation in plants can Induce systemic resistance against various kind of phytopathogens (van Loon et al., 1998). It has been reported that many of rhizobacterial strains act by inducing the systemic resistance in plants against the several plant diseases (Leeman et al., 1995; Park et al., 2009). Antagonistic activity of bacterial strains against fungal pathogens can be confirmed by the formation of inhibition zones between the bacterial isolates and the fungal isolates ( $\mathrm{Ji}$ et al., 2014 or it can be measured by the decrease in mycelia growth of fungal pathogens (Lee $e t$ al., 2017). This inhibition of mycelial growth may be due to the production of antifungal volatile compound (VOCs) by the bacterial strains. It has been reported by Raza et al., (2016) that P. fluorescens WR-1 in Biocontrol because they produce VOCs. Recently the similar result of antifungal activities was also reported by Kandel et al., (2017) and Lee et al., (2017).

Production of siderophores by microbes can enhance iron uptake indicate bacterial ferricsiderophore complex (Masalha et al., 2000; Katiyar and Goel, 2004; Dimkpa et al., 2009). Siderophore production activity can act as Biocontrol activity to suppress the phytopathogens. The role of siderophore production by the microbes in their Biocontrol activity has been studied previously by Solans et al., 2016.

HCN production by the potential microbes can be influenced by several environmental factors (Castric, 1975, 1983;). It was reported by Defago et al., 1990 that Hydrocyanic acid $(\mathrm{HCN})$ produced by many rhizobacterial strains has biological control activity. Voisard et al., (1989) found role of HCN in biological control. The mechanisms of biocontrol viz antagonistic action toward plant pathogens, production of siderophores, cyanide, and hydrolytic enzymes have been reported by the many of researchers (Shaikh and Sayyed 2015). Productions of hydrolytic enzymes against various phytopathogens also play a major role in bio-control (Shaikh and Sayyed 2015). 
Antagonistic activity of potential bacterial stains against
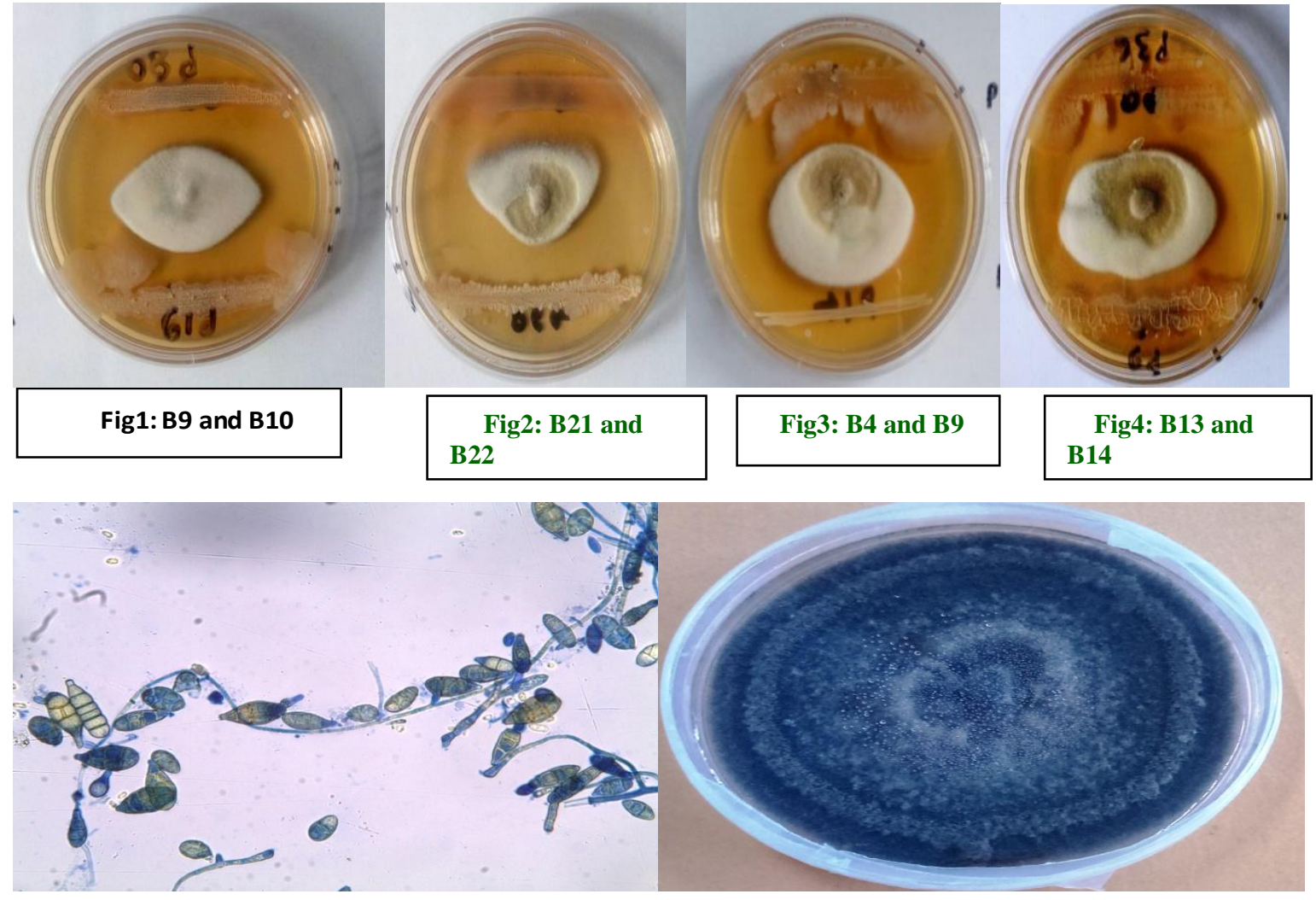

Fig5: Microscopic of Alternaria Brassicae

Fig 6: Pathogen Alternaria Brassicae

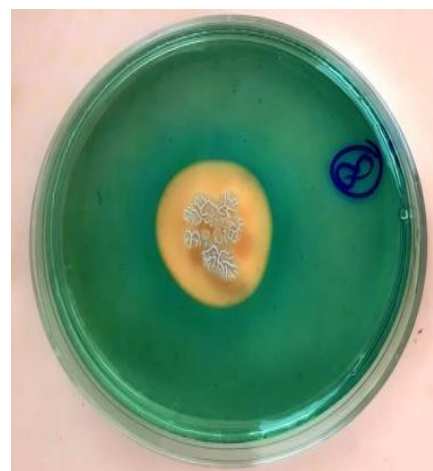

Fig7:Siderophore production

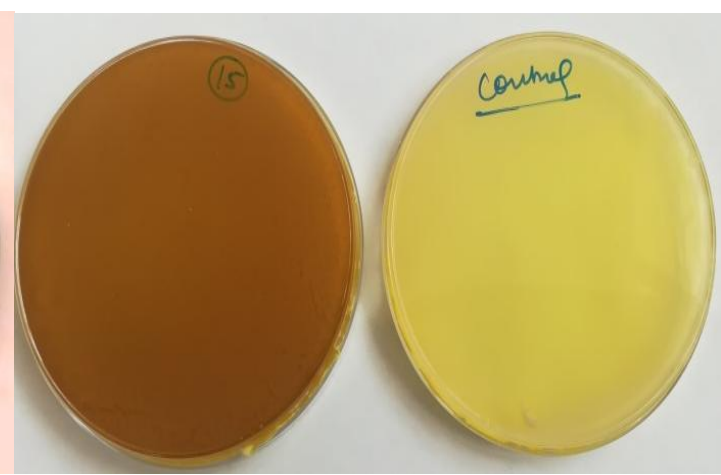

Fig 8: HCN Production and Control

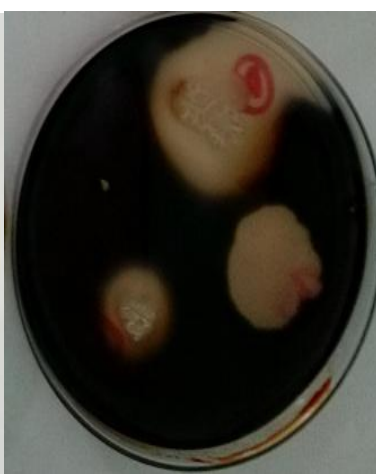

Fig9: Starch hydrolysis 
Table.1 Identification of potential bacterial strains by 16s RNA

\begin{tabular}{|l|c|c|l|}
\hline \multicolumn{4}{|l|}{ Table Molecular characterization of STBA strain to genomic level by 16s rRNA partial } \\
sequencing and their NCBI accession no \\
\hline Isolate code & $\begin{array}{c}\text { Nucleotide base } \\
\text { length (base pair) }\end{array}$ & NCBI accession no. & \multicolumn{1}{|c|}{ Species } \\
\hline B1 & 700 & MK 446245 & Enterobacter xianfangenesis \\
\hline B3 & 650 & MK 418219 & Bacillus FZB42 \\
\hline B9 & 430 & MK 471330 & Enterobacter bugandensis \\
\hline B10 & 530 & MK 463942 & Enterobacter Xianfangenesis \\
\hline B11 & 600 & MK 463943 & Enterobacter Xianfangenesis \\
\hline B14 & 815 & MK 463952 & Enterobacter Xianfangenesis \\
\hline B17 & 600 & MK 478371 & Enterobacter Xianfangenesis \\
\hline B22 & 515 & MK530649 & Paenibacillus alvei \\
\hline
\end{tabular}

Table.2 Plant Growth promoting attributes

\begin{tabular}{|l|l|l|l|l|l|}
\hline $\begin{array}{l}\text { Bacterial } \\
\text { strain } \\
\text { code }\end{array}$ & $\begin{array}{l}\text { Growth at } \\
\mathbf{1 0 \%} \mathbf{N a C l}\end{array}$ & $\begin{array}{l}\text { Antagonist } \\
\text { ic activity } \\
(\boldsymbol{\%})\end{array}$ & $\begin{array}{l}\text { HCN } \\
\text { Production } \\
(\boldsymbol{\%})\end{array}$ & $\begin{array}{l}\text { Siderophore } \\
\text { Production }(\%)\end{array}$ & $\begin{array}{l}\text { Amylase } \\
\text { production } \\
(\%)\end{array}$ \\
\hline B1 & 0.33 & 31.3 & 20 & 56 & 0 \\
\hline B3 & 0.174 & 31.33 & 20 & 55 & 20 \\
\hline B9 & 0.131 & 22.75 & 20 & 0 & 40 \\
\hline B10 & 0.23 & 44.2 & 20 & 63 & 60 \\
\hline B11 & 0.6 & 39.91 & 20 & 55 & 20 \\
\hline B14 & 0.157 & 39.91 & 20 & 28 & 0 \\
\hline B17 & 0.72 & 35.6 & 20 & 63.15 & 20 \\
\hline B22 & 0.39 & 44.2 & 40 & 0 & 0 \\
\hline
\end{tabular}

Studies showed that Biocontrol agents synthesized extracellular hydrolytic enzymes and the enzymes have the potential of inhibiting phytopathogens (Pal and Gardener 2006). Starch hydrolysis can metabolize sugars which can help in better plant growth by increasing germination of seeds (Beck and Ziegler, 1989; Akazawa and Nishimura, 2011).

\section{Acknowledgment}

This research was supported by ICAR- Indian institute of seed sciences and Integral University (IU/R\&D/20A-MCN000675).

\section{References}

Akazawa, T.,and Nishimura, H.(2011). Topographic aspects of bio synthesis, extracellular secretion, and intracellular storage of proteins in plant cells. Annu. Rev. Plan Physiol. $36,441-472$.

ALVES, M. H. et al., Screening of Mucor spp. for the production of amylase, lipase, poly galacturonase and protease. Brazilian Journal of Microbiology, v. 33, n. 4, p. 225-230, 2002.

Ansari, A. N., Khan, M. W. and Muheet, A. 1988. Effect of Alternaria blight on 
oilcontent of rapeseed-mustard, Current Science. 57: 1023-1024.

Atkinson, Nicky J., Catherine J. Lilley, and Peter E. Urwin. "Identification of genes involved in the response of Arabidopsis to simultaneous biotic and abiotic stresses. Plant physiology 162.4 (2013): 2028-2041.

Bernfeld, P. (1955) X Amylases,. and B in : Methods in enzymology. 5 P Colowick and N D Kaplan eds. Vol. I, Academic Press, New York, pp 149-150.

Castric P A 1975 Hydrogen cyanide, a secondary metabolite of Pseudomonas aeruginosa. Can. J. Microbiol. 21, 613-618

Cattelan, A. J., P. G. Hartel, and J. J. Fuhrmann. "Screening for plant growth-promoting rhizobacteria to promote early soybean growth." Soil Science Society of America Journal 63.6 (1999): 1670-1680.

Chomoczynski, P. N. and Sacchi, 1987 Single step method of RNA isolation by acidguanidinium thiocyanate phenolchloroform extraction, Analytical Biochemistry. 162: 156-159.

Defago, G. AND HAAS, D., 1990, Pseudomonads as antagonists of soil borne plant pathogens: mode of action and genetic analysis. Soil Biochemistry, (Eds) Bolley, J.M. and Stortzky, G. New York, Baul, 6: 249291 diazotrophic bacterial community. Plant and Soil, v. 356, n. 1, p. 35-49, 2012.

Diby P, Bharathkumar S, Sudha N (2005a) Osmotolerance in Biocontrol strain of pseudomonas pseudoalcaligenes MSP538: a study using osmolyte, protein and gene expression profiling. Ann Microbiol 55(4):243-47

Elmer WH (2003) Local and systemic effects of $\mathrm{NaCl}$ on root composition, rhizobacteria, and Fusarium crown and root rot of asparagus. Phytopathol
93(2):186-92.

doi:10.1094/PHYTO.2003.93.2.186

Dimkpa, Christian O., et al., "Metal-induced oxidative stress impacting plant growth in contaminated soil is alleviated by microbial siderophores. Soil Biology and Biochemistry 41.1 (2009): 154162.

Ji SH, Gururani MA, Chun SC (2014) Isolation and characterization of plant growth promoting endophytic diazotrophic bacteria from Korean rice cultivars. Microbiol Res 169:83-98. https://doi.org/10.1016/j.micres.2013.0 6.003

Katiyar V and Goel R (2004) Siderophore mediated plant growth promotion at low temperature by mutant of fluorescent pseudomonad. Plant Growth Regul 42:239-244.

Kolte, S. J. 1985. Disease of annual edible oilseed crops, in: Rapeseed Mustard and Sesame Diseases, II: CRC Press, Florida. pp.

Kumar, B., and Kolte S J 2001. Progression of Alternaria blight of mustard in relation to components of resistance. Indian Phytopathology 54: 329-3

Lee T, Park D, Kim K, Lim SM, Yu NH, Kim S, Kim HY, Jung KS, Jang JY, Park JC, Ham H, Lee S, Hong SK, Kim JC (2017) Characterization of Bacillus amyloliquefaciens DA12 showing potent antifungal activity against mycotoxigenic Fusarium species. Plant Pathol J 33:499-507. https://doi.org/10.5423/PPJ.FT.06.201 7.0126

Mahalingam, Ramamurthy. "Consideration of combined stress: a crucial paradigm for improving multiple stress tolerance in plants." Combined stresses in plants. Springer, Cham, 2015. 1-25.

Maksimov IV, Abizgil'dina RR and Pusenkova LI (2011) Plant growth promoting rhizobacteria as alternative 
to chemical crop protectors from pathogens (Review). Appl Biochem Microbiol 47:333-345

Masalha J, Kosegarten H, Elmaci Ö and Mengel K (2000) The central role of microbial activity for iron acquisition in maize and sunflower. Biol Fert Soils 30:433-439.

Meena, P. D., Awasthi, R. P., Chattopadhyay, C., Kolte, S. J. And Kumar, A. 2010. Alternaria blight: a chronic disease in rapeseedmustard. J. Oilseed Brassica. 1: 1-11.

Mittler, R. (2006). Abiotic stress, the field environment and stress combination. Trends Plant Sci. 11, 15-19. doi: 10.1016/j.tplants.2005. 11.002

Narsai, Reena, et al., "Antagonistic, overlapping and distinct responses to biotic stress in rice (Oryza sativa) and interactions with abiotic stress." $B M C$ genomics 14.1 (2013): 93.

Paul D, Nair S (2008) Stress adaptations in a plant growth promoting rhizobacterium (PGPR) with increasing salinity in the coastal agricultural soils. J Basic Microbiol 48(5):378-84. doi:10.1002/jobm. 200700365

Prasch, Christian Maximilian, and Uwe Sonnewald. "Simultaneous application of heat, drought, and virus to Arabidopsis plants reveals significant shifts in signaling networks." Plant physiology 162.4 (2013): 1849-1866.

Ramegowda, Venkategowda, and Muthappa Senthil-Kumar. "The interactive effects of simultaneous biotic and abiotic stresses on plants: mechanistic understanding from drought and pathogen combination." Journal of plant physiology 176 (2015): 47-54.

Rangarajan S, Saleena LM, Vasudevan P, Nair S (2003) Biological suppression of rice diseases by Pseudomonas spp. under saline soil condi t i o n s. Plant Soil
251(1):73-82. doi $\quad: 10.1023$

A:1022950811520

Raupach, Georg S., and Joseph W. Kloepper. "Mixtures of plant growth-promoting rhizobacteria enhance biological control of multiple cucumber pathogens." Phytopathology 88.11

(1998): 1158-1164.

Raza W, Ling N, Liu D, Wei Z, Huang Q, Shen Q (2016) Volatile organic compounds produced by Pseudomonas fluorescens WR-1 restrict the growth and virulence traits of Ralstonia solanacearum. Microbiol Res 192:103-113.

https://doi.org/10.1016/j.micres.2016.0 5.014 reducing sugar. Anal Chem 31: 426-428.

Riungu, G. M., Muthorni, J. W., Narla, R. D., Wagacha, J. M., and Gathumbi, J. K. (2008). Management of Fusarium head blight of wheat and deoxynivalenol accumulation using antagonistic microorganisms. Plant Pathol. J. 7, 1319. doi: 10.3923/ppj.2008.13.19

Roubtsova, T.V., and Bostock, R.M. (2009) Epi sodic abiotic stress as a potential contributing factor to onset and severity of disease caused by Phytophthora ramorum in Rhododendron and Viburnum. Plant Dis 93: 912-918

Solans, Mariana, et al., "Potential biocontrol actinobacteria: rhizospheric isolates from the Argentine Pampas lowlands legumes." Journal of basic microbiology $56.11 \quad$ (2016): 12891298.

Suzuki, N., Rivero, R. M., Shulaev, V., Blumwald, E., \& Mittler, R. (2014). Abiotic and biotic stress combinations. New Phytologist, 203(1), 32-43.

Triky-Dotan S, Yermiyahu U, Katan J, Gamliel A (2005) Development of crown and root rot disease of tomato 
under irrigation with saline water. Phytopathol 95(12):1438-44. doi:10.1094/PHYTO-95-1438

VOISARD, C., KEEL, O., HAAS, P. AND DEFAGO, G., 1989, Cyanide production by Pseudomonas fluorescens helps to suppress black root rot of tobacco under gnotobiotic condition. European Microbiological Journal, 8: 351-358.

Kobayashi, Daisuke, et al., "Endogenous reactive oxygen species is an important mediator of miconazole antifungal effect." Antimicrobial Agents and Chemotherapy 46.10 (2002): 31133117.

Cook, R. James. "Making greater use of introduced microorganisms for biological control of plant pathogens." Annual review of phytopathology 31.1 (1993): 53-80.

Baker, Ralph. "Induction of rhizosphere competence in the biocontrol fungus Trichoderma." The rhizosphere and plant growth. Springer, Dordrecht, 1991. 221-228.

Shrivastava, Pooja, and Rajesh Kumar. "Soil salinity: a serious environmental issue and plant growth promoting bacteria as one of the tools for its alleviation." Saudi journal of biological sciences 22.2 (2015): 123131.

Bakker and Schippers 1987. Microbial cyanide production in the rhizosphere in relation to potato yield reduction and Pseudomonas spp. mediated plant growth stimulation. Soil Biology and Biochemistry 19: 451-457

Schwyn, B., Neilands, J.B., 1997. Universal chemical assay for the detection and determination of siderophores. Anal. BioPesquisa do Estado de Sao Paulo (FAPESP) and chem. 160, 46-56

Van Loon LC, Pierpont WS, Boller T and Conejro V (1994) Recommendations for naming plant pathognesis-related proteins. Plant Mol Biol Rep 12: 245264

Kandel, Shyam L., et al., "An in vitro study of bio-control and plant growth promotion potential of Salicaceae endophytes." Frontiers in microbiology 8 (2017): 386.

Leeman, M., et al., "Induction of systemic resistance against Fusarium wilt of radish by lipopolysaccharides of Pseudomonas

fluorescens." Phytopathology 85.9 (1995): 1021-1027.

Shaikh, S. S., and R. Z. Sayyed. "PGPR: A BOON FOR AGRICULTURE." $\Phi 94$ Фундаментальные и прикладные аспекты создания (2015): 54.

Park, Chang-Jin, and Young-Su Seo. "Heat shock proteins: a review of the molecular chaperones for plant immunity." The plant pathology journal 31.4 (2015): 323.

\section{How to cite this article:}

Kusum Sharma, Swati Sharma, Pawan Sharma and Rajendra Prasad, S. 2019. Exploring of Salt tolerant Biocontrol Agent (STBA) against Phytopathogen of Mustard Crop (Brassicae junecea). Int.J.Curr.Microbiol.App.Sci. 8(09): 2132-2141. doi: https://doi.org/10.20546/ijcmas.2019.809.247 